\title{
Rancangan Aplikasi Pergantian untuk Giliran Kepengurusan Masjid
}

\author{
Rwafemir V. Harari \\ Telkom University \\ Email: Rharary@student.telkomuniversity.ac.id
}

\begin{abstract}
.Masjid adalah tempat beribadah bagi para umat muslim. Banyak kegiatan dan agenda yang dilakukan di masjid, salah satunya adalah ibadah yang dilakukan setiap hari jumat, yaitu yang biasa kita sebut sholat jumat. Sering sekali ditemukan, sebelum sholat jumat kita masih bingung akan giliran siapa untuk menjadi imam, pengkhutbah, \& marbot untuk menyiapkan sarana \& prasaran sholat jumat serta cadangan untuk semua peran. Oleh karena itu, dibuatlah aplikasi pergantian kepengurusan berbasis aplikasi sistem informasi di setiap perangkat pintar, yang bertujuan memudahkan para umat untuk bisa memilih peran apa yang diinginkan sejak hari - $\mathrm{H}$ sebelum sholat jumat berlangsung.
\end{abstract}

Keywords: mosque, substitution, management, pray

Paper ini akan dipublikasikan di osf.io [a] menggunakan format standard perancangan sistem informasi [b]

\section{Introduction}

1.1. Business case

a. Project Definition

Masjid yang merupakan tempat ibadah untuk para umat muslim, banyak agenda dan kegiatan yang dilakukan, salah satunya adalah ibadah sholat jumat. Dimana, kita sering temukan kesalahan informasi dan kesalahan komunikasi dalam pergantian kepengurusan untuk pelaksanaan ibadah sholat jumat. Maka, dibutuhkan aplikasi berbasis informasi pada setiap jemaah calon peran - peran dalam ibadah jumat di tiap perangkat pintar yang memudahkan tiap jemaah.

b. Project Objective

Specific : Menargetkan kepengurusan untuk ibadah jumat.

Measurable : Kesalahan informasi \& kesalahan komunikasi di angka 0 ( tidak adanya kesalahan.)

Attainable : :Tercapainya angka $0 \%$ untuk kesalahan yang ada.

Realistic : Tercapainya target yang realistis dalam waktu yang singkat.

Timebound : Setidaknya dalam 3-4 kali sholat jumat berlangsung, sudah tidak adanya kesalahan yang muncul dan semua jemaah sudah bisa memakai aplikasinya.

c. System Definition

Ide ini berdasarkan pengalaman saya sendiri di masjid sekitar rumah saya dan sesuai di bidang minat yang saya sukai.

\subsection{System Requirement}

a. System Function

Aplikasi ini merupakan aplikasi sistem informasi berbasis data yang memiliki fungsi sebagai berikut :

1. Mencatat data dari calon tiap peran 
2. Mengumpulkan data dari calon tiap peran

3. Menampilkan laporan data tiap peran

b. System Feature

Aplikasi ini memiliki berbagai fitur, diantara nya :

1. Aplikasi memiliki data diri calon tiap peran

2. Aplikasi memiliki data informasi peran apa saja yang sudah diambil

c. Acceptance Criteria

Berikut kriteria penerimaan aplikasi, diantara nya :

1. Aplikasi akan meminta pengguna untuk masuk ( login ) terlebih dahulu untuk masuk dan mengakses

2. User yang telah masuk ( login ), akan diminta memasukkan data diri berupa nama, nomor $\mathrm{HP}$, dan alamat.

3. User yang telah memasukkan data diri, akan diminta memilih peran dan tanggal giliran

4. Pengguna aplikasi dapat melihat informasi peran apa saja yang telah di ambil dan tanggal berapa saja yang sudah terisi.

d. System user level

Aplikasi ini memiliki 3 tingkatan pengguna, yaitu :

1. Admin

Merupakan pengguna dengan tingkat paling tinggi, memiliki semua akses dan bertanggung jawab dengan apa yang didalamnya.

2. Contributor

Merupakan pengguna yang telah mengisi data - data yang diminta di dalam aplikasi saat mengakses nya.

3. Viewer

Merupakan pengguna yang hanya dapat melihat informasi yang disediakan oleh aplikasi.

Click or tap here to enter text.

\section{Penjelasan SIngkat Terkait Metode}

Dalam pengembangan nya, kami menggunakan metode waterfall. Metode ini diyakini relatif mudah dimengerti dan mudah untuk digunakan. Metode ini menekankan pada sebuah alur proses yang sistematis, terlihat seperti aliran air terjun dimulai dari requirements, design, implementation, verification dan terakhir maintenance.

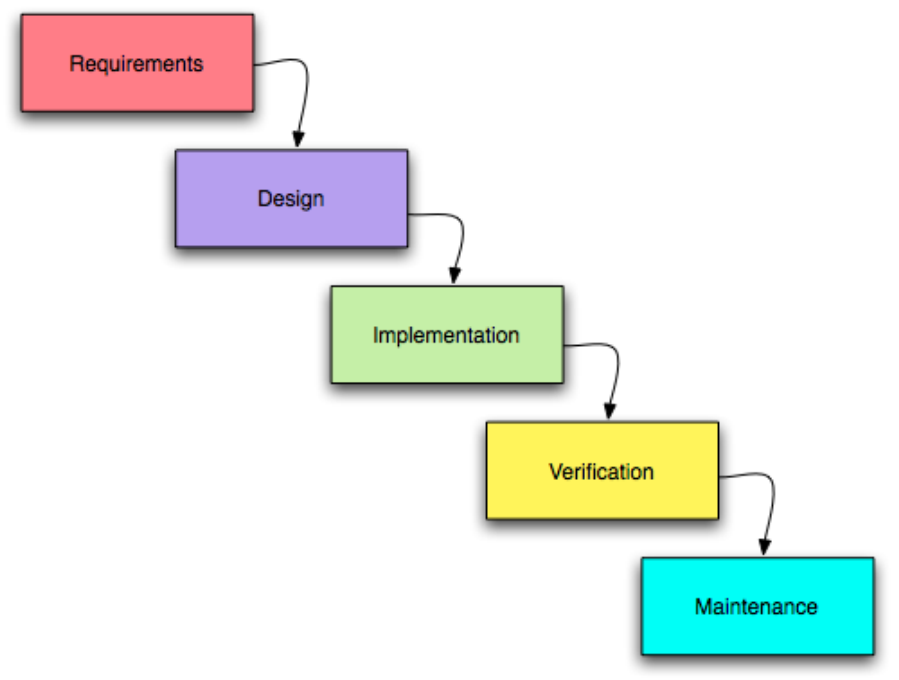

Figure 1 Metode Waterfall 


\section{Proses Perhitungan}

\subsection{System Design}

Sistem di aplikasi bekerja dengan menyimpan data dari tiap calon dengan meminta tiap calon mengisi apa yang diperlukan oleh sistem, kemudian diteruskan kepada admin ( Kepala DKM ). Setelah disetujui oleh admin, sistem akan menampilkan informasi calon tiap peran - peran di tanggal - tanggal yang dipilih oleh calon.

\subsection{Data Flow Diagram (DFD)}

Berikut merupakan DFD dari aplikasi pergantian giliran

DFD Level 0

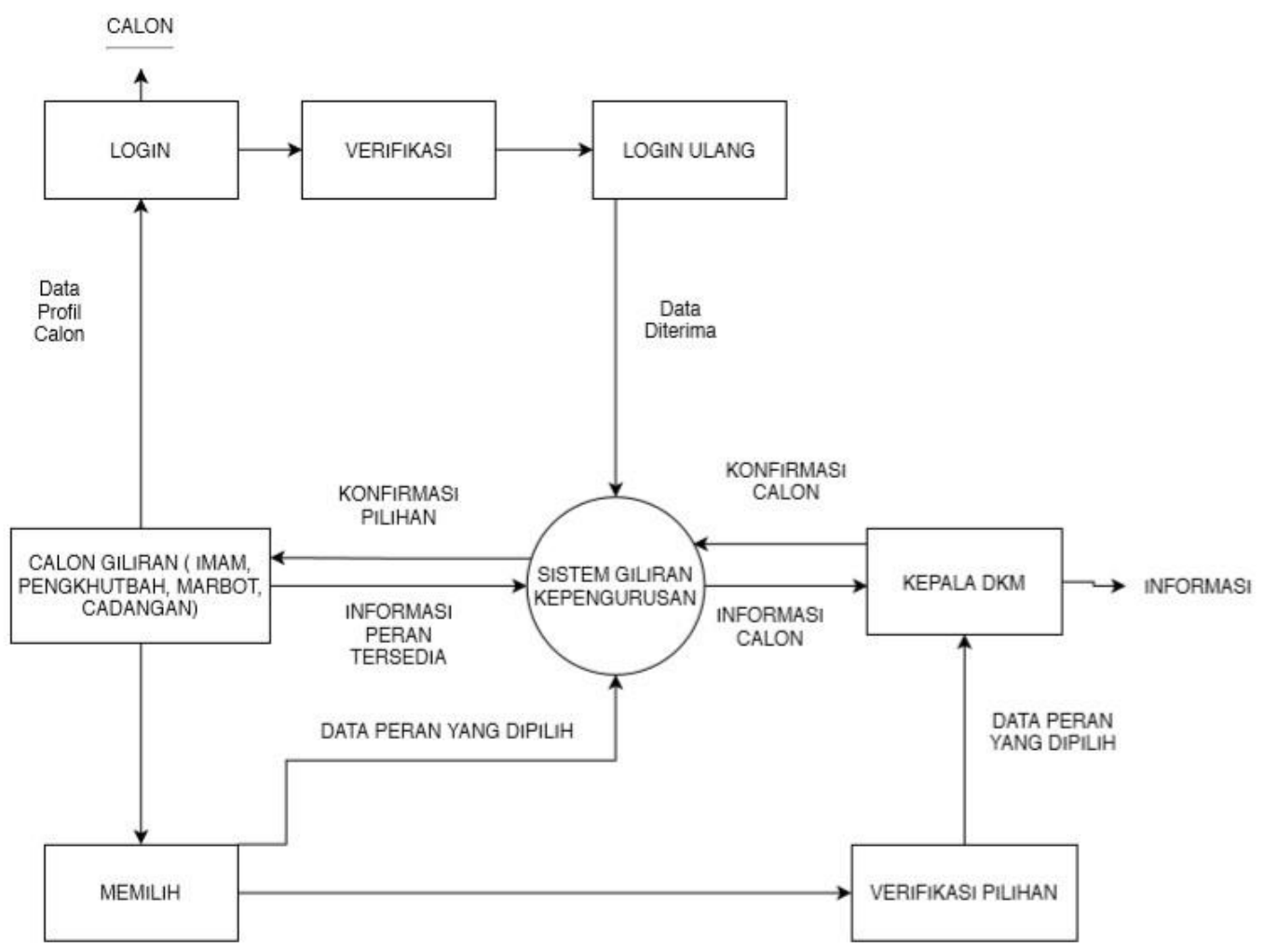

DFD Level 1 


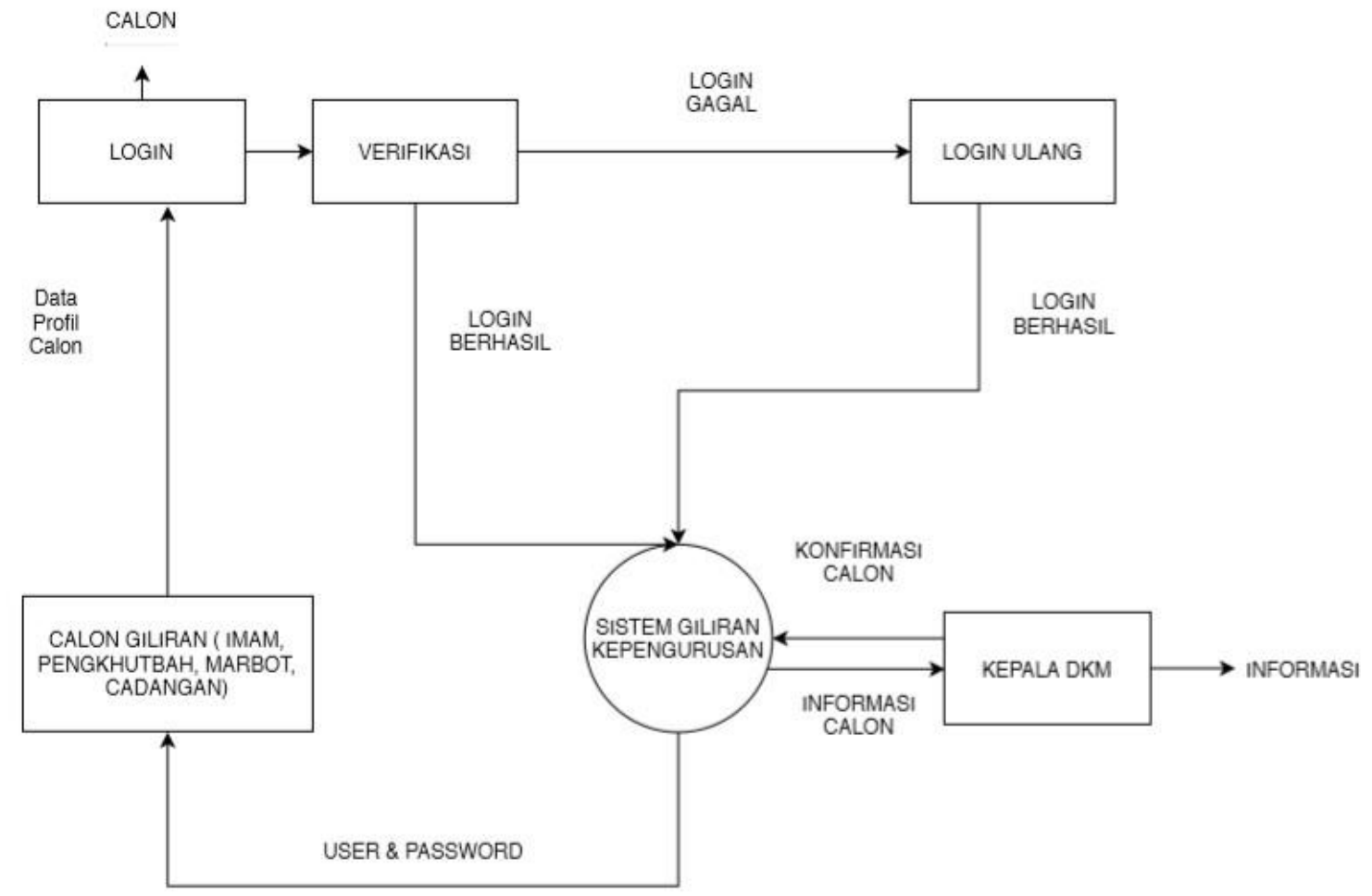

DFD Level 2

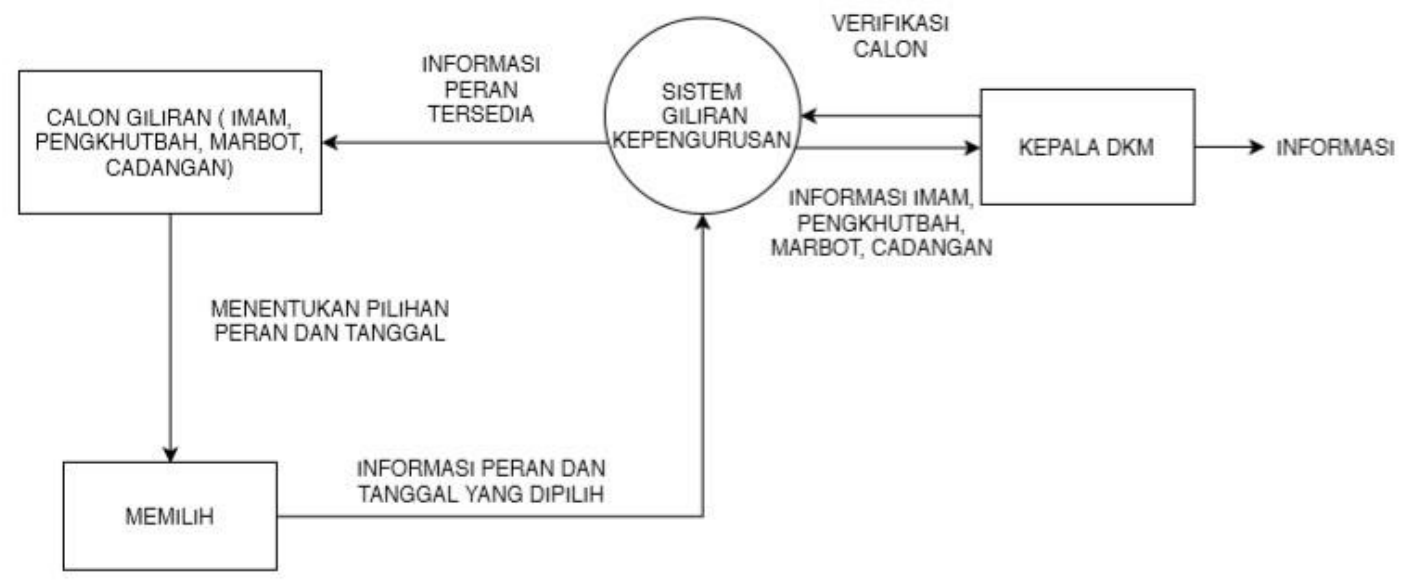

Figure 2 Gambar Data Flow Diagram

3.3. Entity Relationship Diagram (ERD)

Berikut merupakan ERD dari aplikasi pergantian giliran 


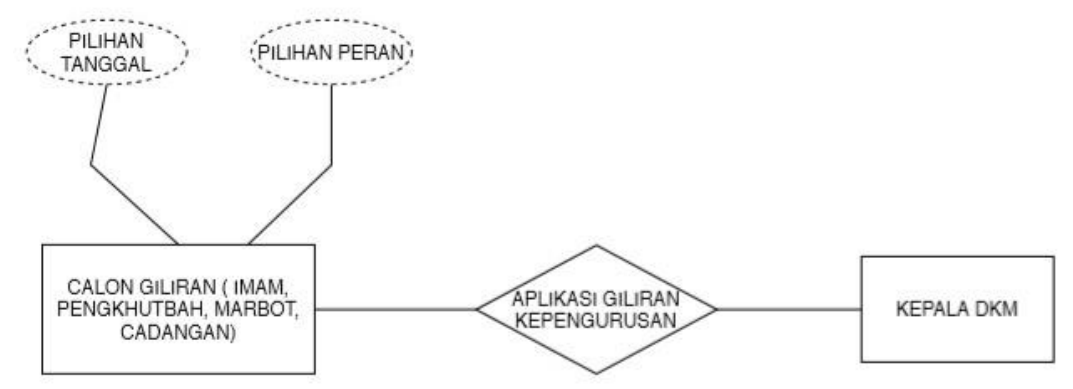

Figure 4 Gambar ERD

\subsection{Database Design}

Data - data yang terdapat didalamnya adalah nomor urut, nama, nomor HP, tanggal yang dipilih, dan peran yang dipilih.

\subsection{Use Case Diagram}

Berikut merupakan Use Case Diagram dari aplikasi pergantian giliran, yang salah satu fungsi nya adalah untuk memasukkan data diri.

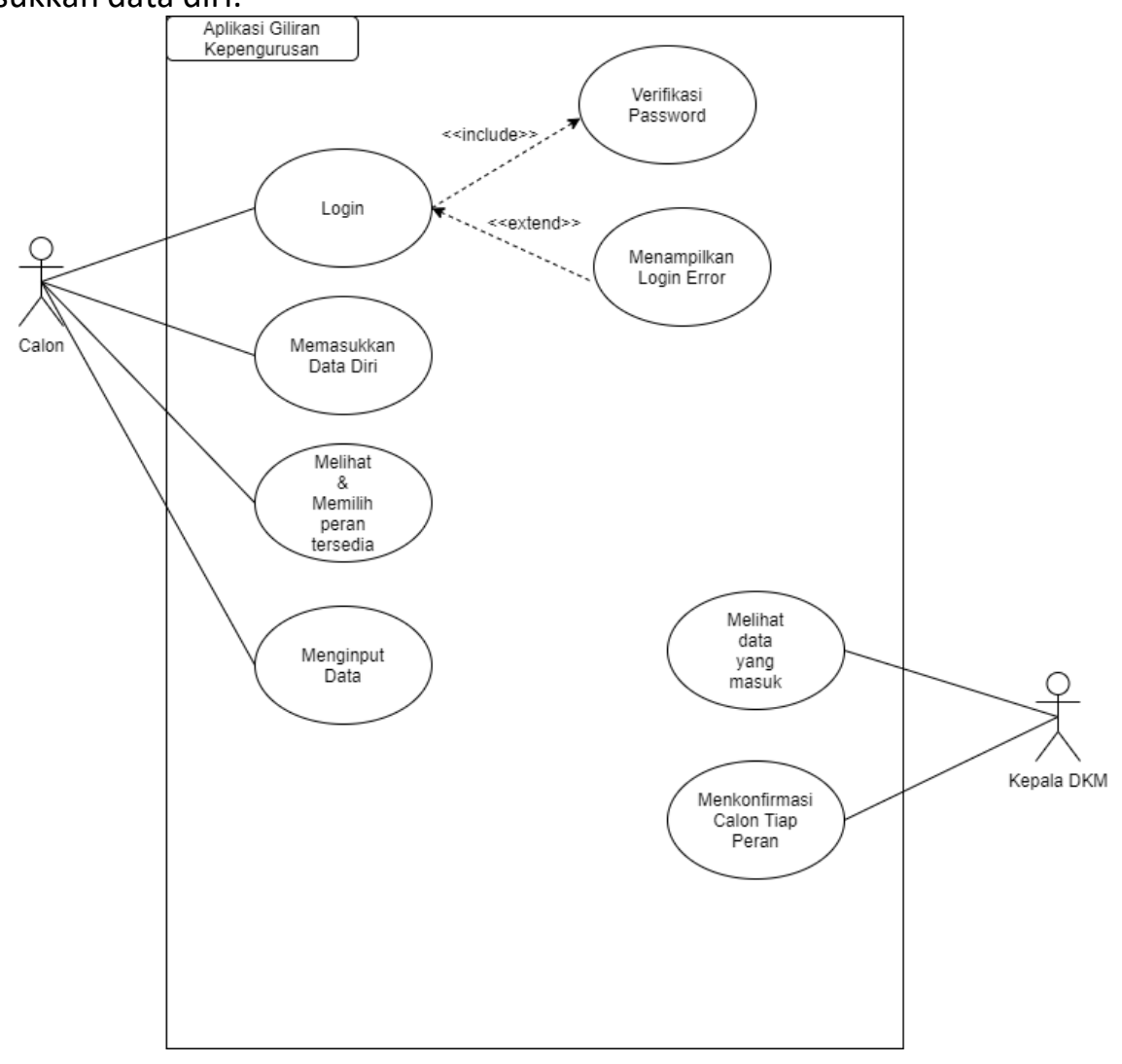

Figure 5 Gambar Use Case Diagram

3.6 Activity Diagram

Berikut merupakan Activity Diagram dari aplikasi pergantian giliran, yang fungsi nya mengetahui aktifitas dari user ( calon ), system dan admin (Kepala DKM ). 


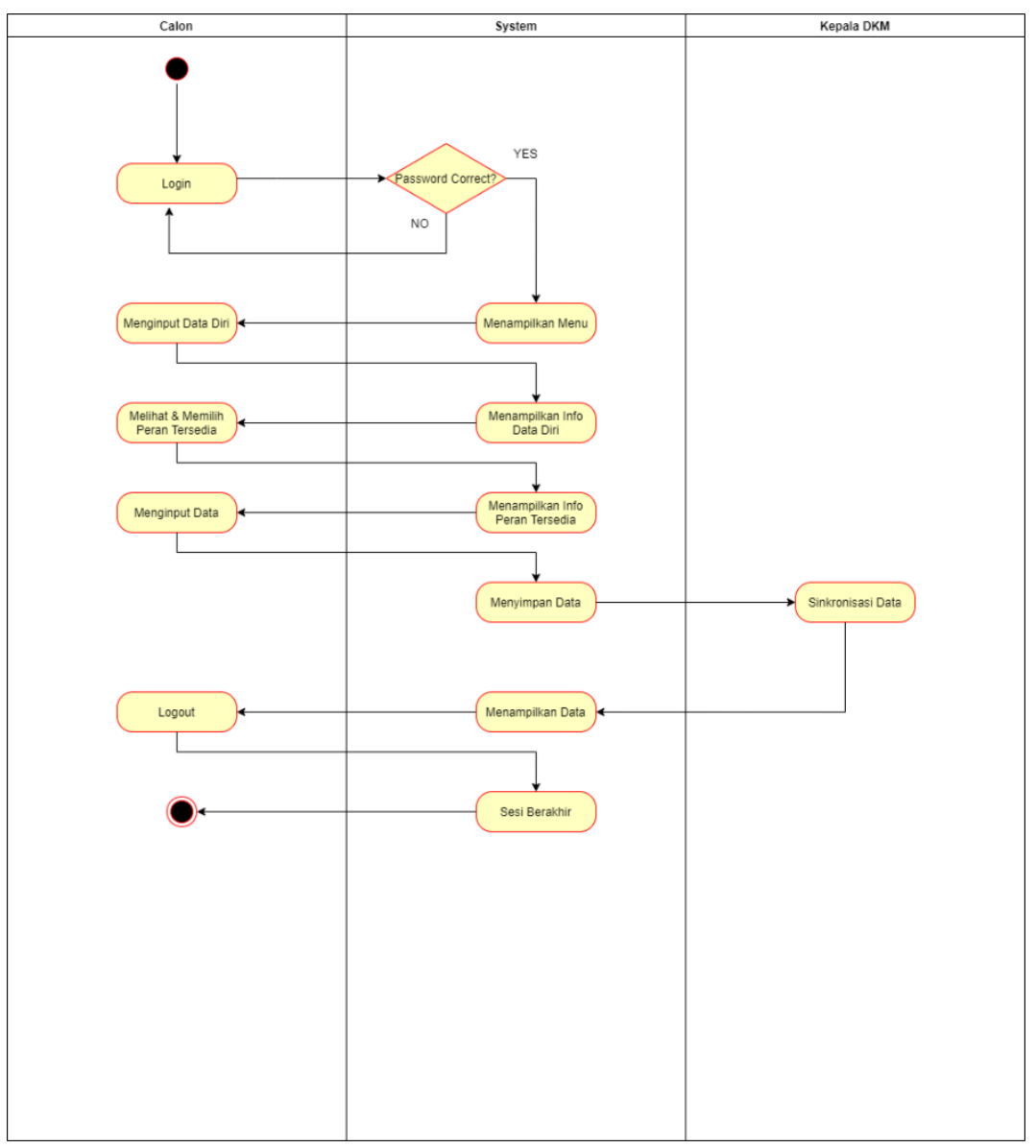

Figure 6 Gambar Activity Diagram

3.7 Sequence Diagram

Berikut merupakan Sequence Diagram, yang salah satu fungsi nya adalah mengetahui alur proses system dari aplikasi.

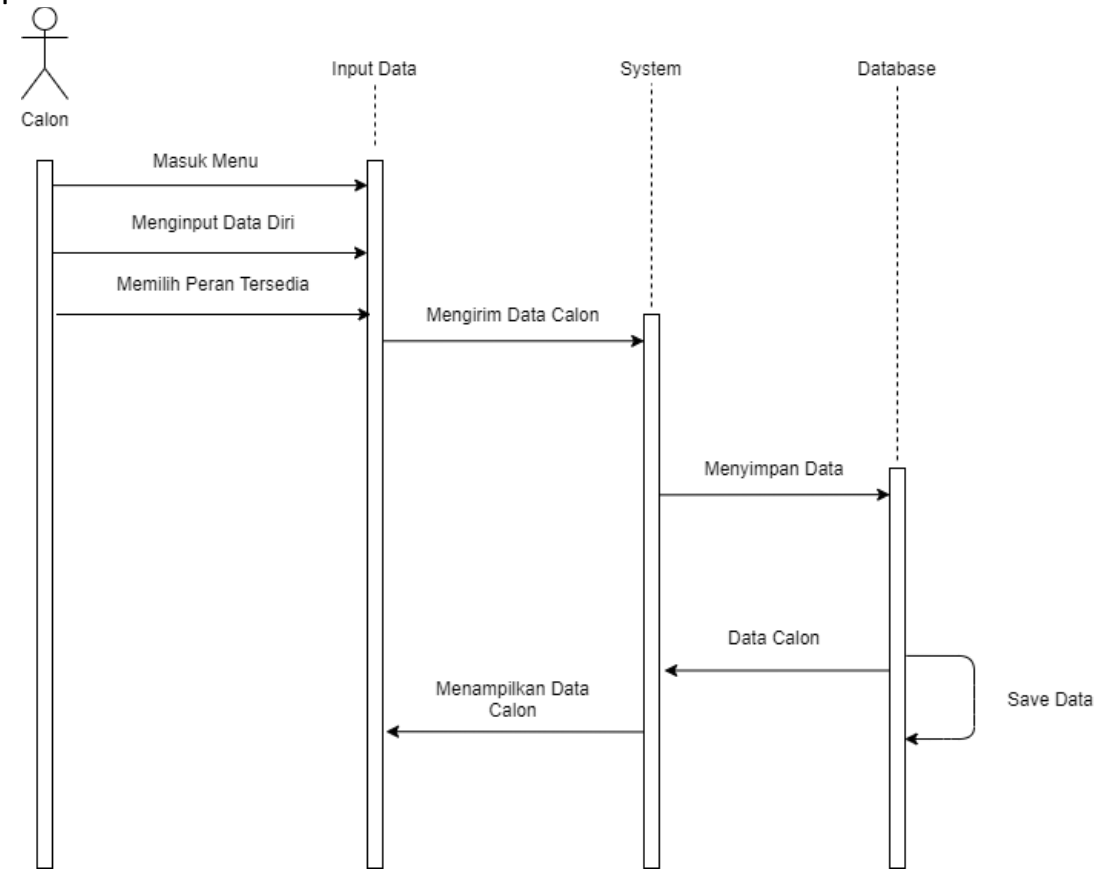

Figure 7 Gambar Sequence Diagram 


\subsection{Interface Design}

Berikut merupakan Interface Design dari aplikasi pergantian giliran.

Bagian Form

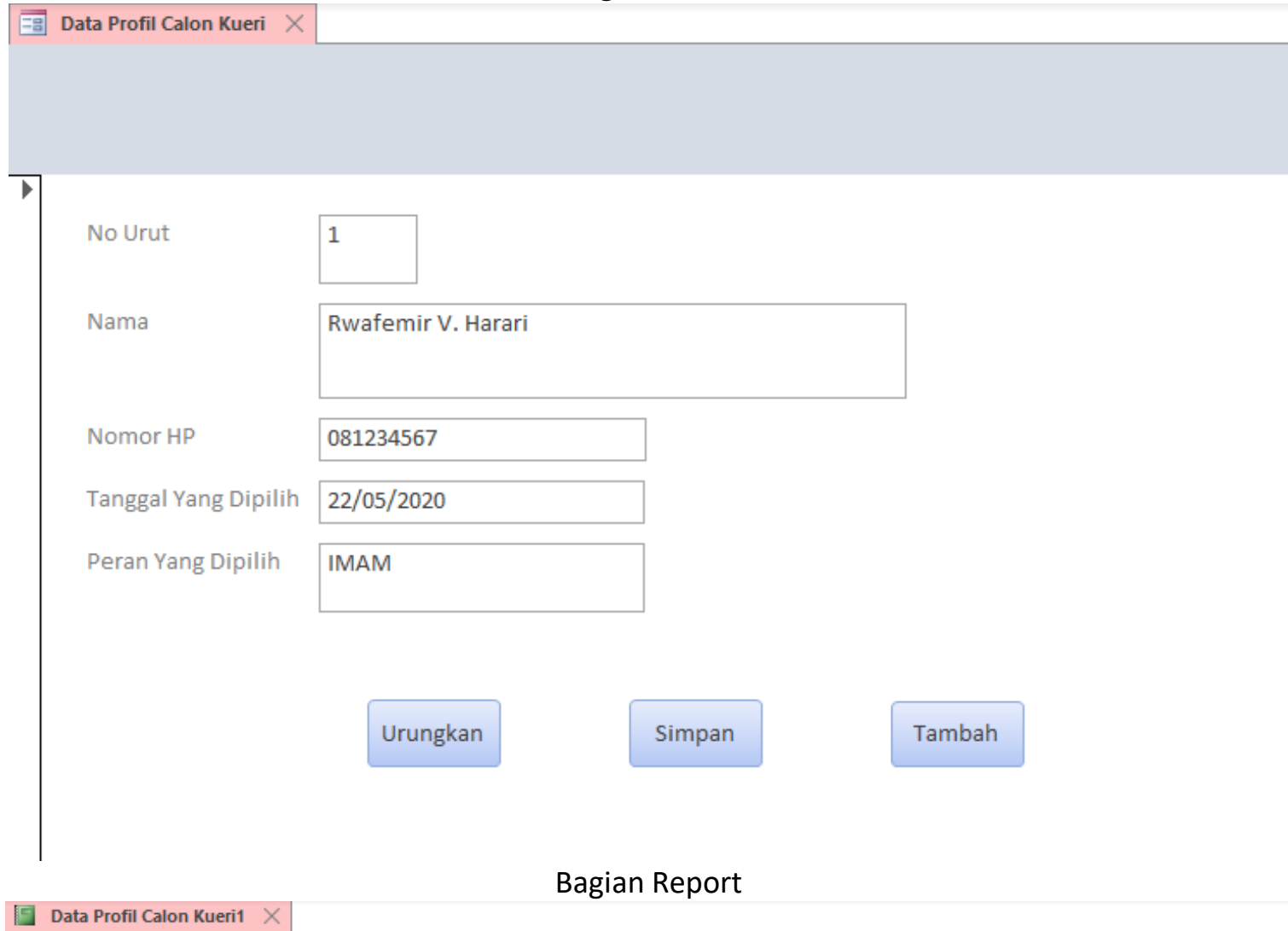

\section{Data Profil Calon}

No Urut

1

2

3

30 May 2020
Nomor HP Tanggal Yang Dipilih Peran Yang Dipilih

Rwafemir V. Harari Nahrowi Al Muslim

Asep Sarmintoro

Heru Sulaiman
081234567

081124567

0878987456

08984521
$22 / 05 / 2020$

22/05/2020

$22 / 05 / 2020$

$22 / 05 / 2020$

Halaman dari

Figure 8 Gambar Interface Design

\subsection{Source Code}




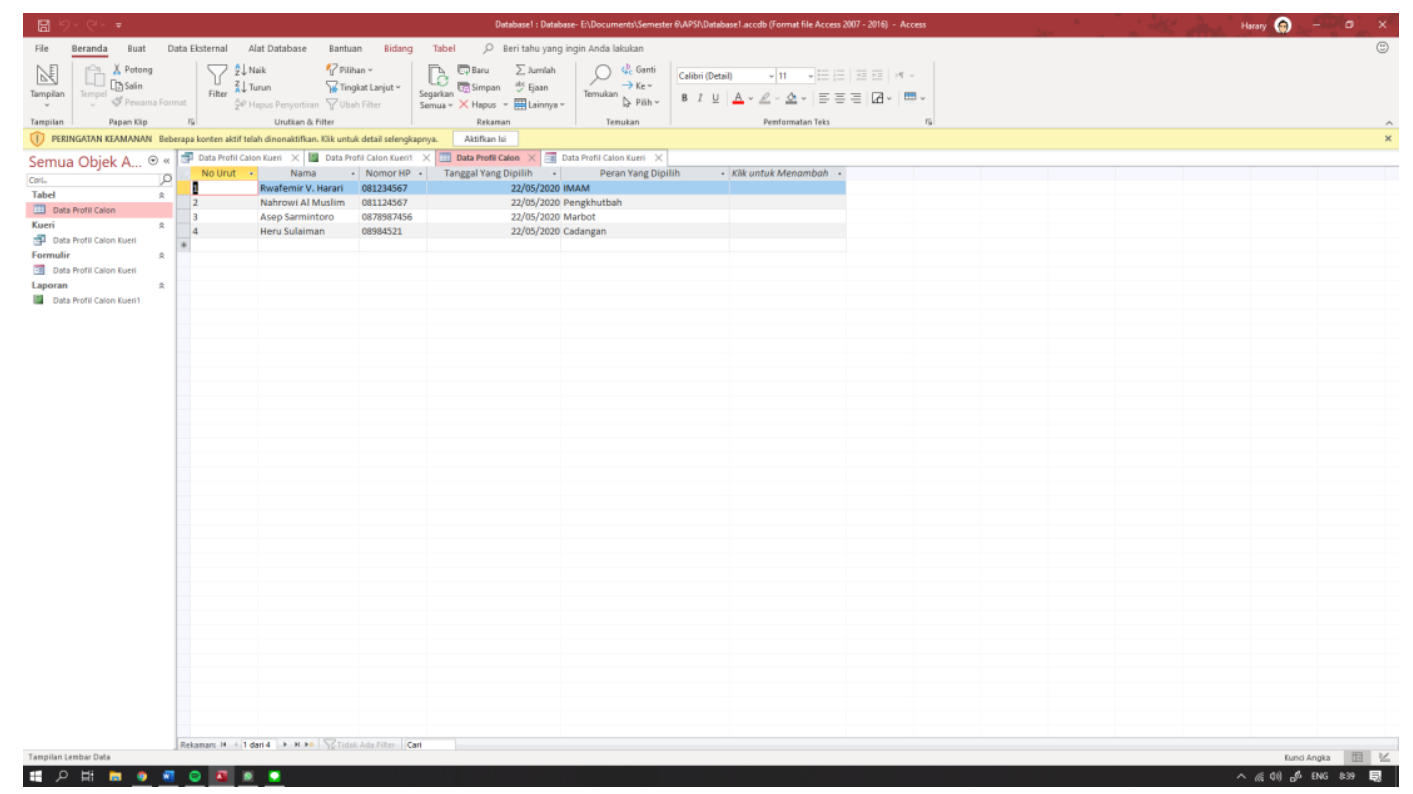

\section{Penutup}

4.1 Kesimpulan

Aplikasi pergantian giliran ini merupakan sebuah solusi bagi kepengurusan juga jamaah masjid untuk lebih mudah saling bertukar informasi, mengurangi kesalahan komunikasi dan informasi, juga mengetahui giliran kepengurusan serta informasi lainnya. Aplikasi ini juga berguna disaat kita sedang new normal, guna menghindari atau mengurangi kontak fisik dan social distancing dengan sesama. Dengan aplikasi ini, kepengurusan akan jauh lebih informatif dan sistematis dibanding sebelumnya.

\subsection{Saran}

Untuk penelitian selanjutnya, diharapkan aplikasi ini dapat digunakan sampai maksimal. Diharapkan juga dapat banyak pengembang yang ingin membuat aplikasi terus berkembang dan bekerja sama dengan banyak platform serta banyak diterapkan di tiap - tiap masjid agar kepengurusan menjadi lebih informatif serta sistematis.

\section{References}

[1]R. Aurachman, "Review Terhadap OSF.IO Sebagai Sarana Publikasi Preprint, " OSF Preprints, 17 May 2020.

[2] R. Aurachman, "Kerangka Perancangan Sistem Informasi Sebagai Pembelajaran Mahasiswa Teknik Industri," osf.io, 52020.

Additional

[a] R. Aurachman, "Review Terhadap OSF.IO Sebagai Sarana Publikasi Preprint," OSF Preprints, 17 May 2020. doi:10.31219/osf.io/rvumx , Available: https://osf.io rvumx

[b] R. Aurachman, "Kerangka Perancangan Sistem Informasi Sebagai Pembelajaran Mahasiswa Teknik Industri," osf.io, doi:10.31219/osf.io/tmpen , 5 2020. Available: https://osf.io/tmpcn 